\title{
МОЖЛИВОСТІ ВЕРИФІКАЦІЇ КОРОТКОСТРОКОВОГО ВІТАЛЬНОГО ПРОГНОЗУ У ПАЦІЕНТІВ ЗІ СПОНТАННИМ СУПРАТЕНТОРІАЛЬНИМ ВНУТРІШНЬОМОЗКОВИМ КРОВОВИЛИВОМ НА ТЛІ КОНСЕРВАТИВНОЇ ТЕРАПІЇ НА ПІДСТАВІ КОМПЛЕКСНОГО КЛІНІКО-НЕЙРОВІЗУАЛІЗАЦІЙНО-ЕЛЕКТРОЕНЦЕФАЛОГРАФІЧНОГО ДОСЛІДЖЕННЯ
}

\author{
๑О. А. Козьолкін, А. А. Кузнєцов \\ Запорізький державний медичний університет Міністерства охорони здоров'я України
}

РЕзюМЕ. Мета - розробити інтегральні критерії прогнозування летального виходу гострого періоду спонтанного супратенторіального внутрішньомозкового крововиливу на тлі консервативної терапії, які ґрунтуються на результатах комплексного клініко-нейровізуалізаційно-електроенцефалографічного дослідження.

Матеріал і методи. Проведено проспективне когортне порівняльне дослідження 156 пацієнтів у гострому періоді спонтанного супратенторіального внутрішньомозкового крововиливу на тлі консервативної терапії, які були госпіталізовані протягом 24 годин від дебюту захворювання. Клініко-неврологічне дослідження включало оцінку за шкалою коми Full Outline of UnResponsiveness та National Institute of Health Stroke Scale. Візуалізацію церебральних структур здійснювали методом комп'ютерної томографії. Електроенцефалографічне дослідження проводили в перші 48 годин, при цьому окремо для ураженої гемісфери та інтактної гемісфери визначали рівні абсолютної спектральної потужності ритмів дельта-, тета-, альфа-, бета-діапазонів із наступним розрахунком інтегральних коефіцієнтів, які відображають різні співвідношення зазначених вище ритмів. Для розробки критеріїв прогнозування застосовували логістичний регресійний аналіз та ROC-аналіз.

Результати. Летальний вихід протягом гострого періоду захворювання був зафіксований в 42 (26,9 \%) випадках. На підставі мультиваріантного логістичного регресійного аналізу було встановлено, що з ризиком летального виходу гострого періоду спонтанного супратенторіального внутрішньомозкового крововиливу на тлі консервативної терапії незалежно асоційовані такі клініко-нейровізуалізаційно-електроенцефалографічні критерії оцінки тяжкості ураження церебральних структур у дебюті захворювання: сумарний бал за шкалою коми Full Outline of UnResponsiveness (ВШ $(95 \%$ ДІ) = 0,29 $(0,13-0,69)$, p=0,0050), обсяг осередку ураження (ВШ $(95 \%$ ДІ) =1,05 $(1,01-$ 1,10), p=0,0270), значення коефіцієнта DTABR в ураженій гемісфері (ВШ $(95 \%$ ДI) = 1,70 $(1,14-1,53), p=0,0092)$ та коефіцієнта DTR в інтактній півкулі (ВШ (95\% ДІ) = 1,60 (1,02-2,53), p=0,0412).

Висновки. Розроблена математична модель для прогнозування летального виходу гострого періоду спонтанного супратенторіального внутрішньомозкового крововиливу на тлі консервативної терапії, яка ґрунтується на результатах комплексного клініко-нейровізуалізаційно-електроенцефалографічного дослідження в дебюті захворювання (AUC=0,99, p<0,0001; точність прогнозування 97,4\%).

КЛючОВІ СлОВА: внутрішньомозковий крововилив; комп'ютерна томографія; електроенцефалографія; вітальний прогноз.

Вступ. Мозкові інсульти - одна з провідних причин захворюваності, смертності та інвалідизації дорослого населення не тільки в Україні, а й у більшості країн світу $[1,2]$. Найбільш небезпечним типом мозкового інсульту є спонтанний внутрішньомозковий крововилив, який відрізняється найбільшими показниками летальності в гострому періоді захворювання [3].

Своєчасний вибір оптимальної тактики ведення зазначеного контингенту хворих є однією з найскладніших і поки що не вирішених проблем сучасної ангіоневрології $[4,5]$. На теперішній час не викликає сумнівів провідна роль верифікації короткострокового прогнозу в якості підґрунтя для прийняття диференційованих лікувально-тактичних рішень $[6,7]$. У багатьох дослідженнях доведена висока прогностична цінність клініко-нейровізуалізаційних критеріїв оцінки тяжкості ураження церебральних структур у пацієнтів зі спонтанним супратенторіальним внутрішньомозковим крововиливом [8-11]. На прикладі Intracerebral Hemorrhage
Scale переконливо продемонстрована доцільність інтегративного підходу до оцінки клініко-неврологічних та нейровізуалізаційних показників для стратифікації індивідуального ризику летального виходу гострого періоду спонтанного внутрішньомозкового крововиливу $[12,13]$.

Перспективним вбачається підвищення точності прогнозування шляхом доповнення комплексу діагностичних процедур інформативними методами об'єктивізації стану церебральних структур в найгострішому періоді захворювання. 3 огляду на вищенаведене, привертає до себе увагу комп'ютерна електроенцефалографія як вельми інформативний метод оцінки функціонального стану головного мозку $[14,15]$. Додатковими перевагами електроенцефалографічного дослідження $є$ мілісекундна роздільна здатність, неінвазивність та економічна доступність, а застосування спектрального аналізу дозволяє розраховувати на суттєве підвищення інформативності вказаного методу, що було продемонстровано у 
Огляди літератури, оригінальні дослідження, погляд на проблему, випадок з практики, короткі повідомлення пацієнтів з гострими пошкодженнями головного мозку ішемічного та травматичного ґенезу [16-18].

Мета - розробити інтегральні критерії прогнозування летального виходу гострого періоду спонтанного супратенторіального внутрішньомозкового крововиливу на тлі консервативної терапії, які ґрунтуються на результатах комплексного клініко-нейровізуалізаційно-електроенцефалографічного дослідження.

Матеріал і методи дослідження. Проведено проспективне когортне порівняльне клінікопараклінічне дослідження 156 пацієнтів (90 чоловіків та 66 жінок, середній вік $(66,7 \pm 0,8)$ років) із верифікованим за даними клініко-нейровізуалізаційного обстеження гіпертензивним ССВМК, що виник уперше, які були госпіталізовані у відділення гострих порушень мозкового кровообігу Комунального некомерційного підприємства «Міська лікарня № 6» Запорізької міської ради протягом 24 годин від дебюту захворювання. Обов'язковою була наявність підписаної інформованої згоди на участь пацієнта у дослідженні, яке здійснювалося в суворій відповідності вимогам Гельсінкської декларації Всесвітньої медичної асоціації про етичні принципи проведення наукових медичних досліджень за участю людини (1964-2008 рр.), директиви Європейського товариства 86/609 про участь людей в медико-біологічних дослідженнях, а також наказу МОЗ України № 690 від 23.09.2009 р., що підтверджувалося висновком Комісії з питань етики Запорізького державного медичного університету (протокол № 1 від 27.01.2016 року).

Клініко-неврологічне дослідження включало оцінку за шкалою коми Full Outline of UnResponsiveness (FOUR) та National Institute of Health Stroke Scale (NIHSS) під час надходження до стаціонару та в динаміці перебігу гострого періоду захворювання.

Для візуалізації церебральних структур використовували комп'ютерний томограф «Siemens Somatom Spirit» (Федеративна Республіка Німеччина). На підставі нейровізуалізаційного дослідження визначали обсяг внутрішньомозкового крововиливу (ОВМК), наявність вторинної внутрішньошлуночкової геморагії (ВВШГ), вираженість зсуву серединних структур мозку.

Критеріями виключення з дослідження були: 1) гострі порушення мозкового кровообігу в анамнезі; 2) 22 осередки ураження церебральних структур; 3) наявність аневризми чи артеріовенозної мальформації церебральних судин, підтвердженої за даними нейровізуалізаційного дослідження чи автопсії; 4) вторинний генез внутрішньомозкового крововиливу (внаслідок ішемічного інсульту, пухлини головного мозку, прийому антикоагулянтів); 5) наявність показань до оперативного лікування

(за результатами консультації нейрохірурга); 6) соматична патологія в стадії декомпенсації; 7) злоякісні новоутворення; 8) екстрацеребральна причина летального виходу (за даними аутопсії).

Електроенцефалографічне дослідження проводилося в перші 48 годин від дебюту ССВМК за допомогою 21-канального електроенцефалографа «NeuroCom» виробництва «XAІ-Медика» (Україна). Електроди встановлювали за міжнародною системою «10-20». Для спектрального аналізу відбирали безартефактну епоху фонової проби тривалістю 30 секунд, при цьому окремо для ураженої гемісфери (УГ) та інтактної гемісфери (ІГ) визначалися рівні абсолютної спектральної потужності ритмів (АСПР) дельта-, тета-, альфа-, бета-діапазонів (мкB2) з наступним розрахунком інтегральних коефіцієнтів, які відображають різні співвідношення зазначених вище ритмів:

1) $\mathrm{DTABR}=($ АCПР дельта-діапазону + АCПР тетадіапазону) / (АСПР альфа-діапазону + АСПР бета-діапазону);

2) $\mathrm{DTR}=$ ACПP дельта-діапазону / ACПР тетадіапазону;

3) DAR = ACחР дельта-діапазону / АCПР альфадіапазону;

4) TAR = ACПР тета-діапазону / АСПР альфадіапазону;

5) $\mathrm{ABR}=\mathrm{ACПP}$ альфа-діапазону / АCПР бетадіапазону.

Усі пацієнти отримували консервативну терапію згідно з Уніфікованим протоколом надання медичної допомоги пацієнтам із мозковим геморагічним інсультом, затвердженим наказом Міністерства охорони здоров'я України № 275 від 17.04.2014 року [19].

Статистичний аналіз результатів проводили з використанням програм Statistica 13.0 (StatSoft Inc., USA, серійний номер JPZ804I382130ARCN10J) та MedCalc (version 18.2.1). Оскільки більшість показників мала розподіл, що відрізнявся від нормального (згідно з результатами тесту ШапіроУїлка), описова статистика подана у вигляді медіани та міжквартильного інтервалу, міжгрупові відмінності досліджуваних кількісних та якісних показників визначали за допомогою критеріїв Манна-Уітні та $\chi^{2}$ відповідно. Для розробки критеріїв прогнозування застосовували логістичний регресійний аналіз та ROC-аналіз. Для побудови мультиваріантної моделі бінарної логістичної регресії використовували предиктори з рівнями статистичної значущості $p<0,05$ за даними уніваріантного логістичного регресійного аналізу та p>0,05 згідно з тестом Хосмера-Лемешова.

Результати й обговорення. Летальний вихід (ЛВ) протягом гострого періоду захворювання був зафіксований в 42 (26,9 \%) випадках. Встанов- 
Огляди літератури, оригінальні дослідження, погляд на проблему, випадок з практики, короткі повідомлення лено, що пацієнти, у яких гострий період ССВМК мав ЛВ, в 1 добу захворювання відрізнялися більш тяжким ураженням церебральних структур

за даними клініко-неврологічного, нейровізуалізаційного та електроенцефалографічного досліджень (табл. 1).

Таблиця 1. Порівняльний аналіз результатів клініко-нейровізуалізаційно-електроенцефалографічного дослідження у пацієнтів зі спонтанним супратенторіальним внутрішньомозковим крововиливом у зіставленні з виходом гострого періоду захворювання

\begin{tabular}{|c|c|c|c|}
\hline Показники & Летальний вихід (n=42) & Нелетальний вихід (n=114) & $p$ \\
\hline Вік, роки & $65(55 ; 76)$ & $66(61 ; 76)$ & 0,1625 \\
\hline FOUR, бал & $8(5 ; 14)$ & $16(15 ; 16)$ & $<0,0001$ \\
\hline NIHSS, бал & $27(19 ; 30)$ & $11(7 ; 16)$ & $<0,0001$ \\
\hline Обсяг осередку ураження, мл & $56,0(27,1 ; 91,7)$ & $8,5(3,5 ; 15,0)$ & $<0,0001$ \\
\hline Зсув прозорої перетинки, мм & $8(4 ; 11)$ & $1(0 ; 3)$ & $<0,0001$ \\
\hline Зсув епіфіза, мм & $6(3 ; 10)$ & $1(0 ; 3)$ & $<0,0001$ \\
\hline АСПР дельта УГ, мкВ² & $74,9(46,8 ; 129,0)$ & $13,2(5,5 ; 35,0)$ & 0,0000 \\
\hline АСПР тета УГ, мкВ² & $20,0(10,0 ; 40,1)$ & $14,9(9,2 ; 33,1)$ & 0,1596 \\
\hline АСПР альфа УГ, мкВ² & $5,9(3,6 ; 7,4)$ & $14,3(8,8 ; 26,0)$ & $<0,0001$ \\
\hline АСПР бета УГ, мкВ² & $2,9(2,0 ; 5,0)$ & $7,0(5,1 ; 9,1)$ & $<0,0001$ \\
\hline АСПР загальна УГ, мкВ² & $103,4(77,9 ; 196,9)$ & $61,8(41,9 ; 100,3)$ & $<0,0001$ \\
\hline АСПР дельта ІГ, мкВ² & $106,1(57,6 ; 159,9)$ & $14,8(6,4 ; 36,9)$ & $<0,0001$ \\
\hline АСПР тета IГ, мкВ² & $32,7(20,1 ; 68,4)$ & $15,9(10,3 ; 34,6)$ & 0,0011 \\
\hline АСПР альфа ІГ, мкВ² & $6,3(4,0 ; 9,8)$ & $17,5(9,5 ; 30,2)$ & $<0,0001$ \\
\hline АСПР бета ІГ, мкВ² & $4,0(2,3 ; 6,2)$ & $7,3(4,7 ; 10,2)$ & $<0,0001$ \\
\hline АСПР загальна ІГ, мкВ² & $142,3(91,4 ; 232,1)$ & $67,6(47,3 ; 97,3)$ & $<0,0001$ \\
\hline DTABR УГ & $12,98(6,56 ; 21,28)$ & $1,46(0,61 ; 4,24)$ & $<0,0001$ \\
\hline DTR УГ & $3,73(1,61 ; 6,00)$ & $0,95(0,46 ; 1,72)$ & $<0,0001$ \\
\hline DAR УГ & $14,24(9,73 ; 23,90)$ & $1,07(0,28 ; 3,15)$ & $<0,0001$ \\
\hline TAR УГ & $4,65(2,18 ; 7,04)$ & $1,25(0,54 ; 2,56)$ & $<0,0001$ \\
\hline ABR УГ & $1,36(0,96 ; 2,75)$ & $2,24(1,50 ; 3,42)$ & 0,0115 \\
\hline DTABR IГ & $11,54(7,90 ; 24,19)$ & $1,28(0,69 ; 3,74)$ & $<0,0001$ \\
\hline DTR II & $2,75(2,13 ; 4,53)$ & $0,94(0,46 ; 1,43)$ & $<0,0001$ \\
\hline DAR II & $14,73(9,85 ; 24,77)$ & $0,78(0,35 ; 2,81)$ & $<0,0001$ \\
\hline TAR IT & $5,35(2,61 ; 7,73)$ & $0,89(0,50 ; 2,73)$ & $<0,0001$ \\
\hline ABR II & $1,60(0,95 ; 2,66)$ & $2,49(1,42 ; 3,97)$ & 0,0016 \\
\hline
\end{tabular}

Зазначена когорта пацієнтів під час госпіталізації до стаціонару характеризувалася глибшим неврологічним дефіцитом за шкалою NIHSS (27 $(19 ; 30)$ балів проти $11(7 ; 16)$ балів, p<0,0001) та більш вираженими клінічними ознаками дисфункції стовбурових структур за шкалою коми FOUR (8 (5; 14) балів проти $16(15 ; 16)$ балів, p<0,0001) унаслідок більшого обсягу осередку ураження $(56,0(27,1 ; 91,7)$ мл проти $8,5(3,5 ; 15,0)$ мл, $\mathrm{p}<0,0001)$ та латерального зсуву стовбурових структур - прозорої перетинки $(8(4 ; 11)$ мм проти $1(0 ; 3)$ мм, p<0,0001) та епіфіза $(6(3 ; 10)$ мм проти $1(0 ; 3)$ мм, p<0,0001). Частота виявлення вторинної внутрішньошлуночкової геморагії також була вищою (95,2 \% проти 52,6 \%, критерій $\chi^{2}=37,3$, $p<0,0001)$

У структурі ЕЕГ-патерну в обох півкулях у зазначеного контингенту хворих домінувала по- вільнохвильова активність, про що свідчили значення інтегрального коефіцієнта DTABR в УГ та IГ відповідно $12,98(6,56 ; 21,28)$ та $11,54(7,90 ; 24,19)$, при цьому переважали ритми дельта-діапазону значення інтегральних коефіцієнтів DTR в УГ та IГ склали відповідно $3,73(1,61 ; 6,00)$ та 2,75 (2,13; 4,53), DAR - 14,24 $(9,73 ; 23,90)$ та $14,73(9,85 ; 24,77)$. Варто зазначити, що у вказаної групи пацієнтів рівні АСПР дельта-діапазону в ІГ були вищими $\left(106,1(57,6 ; 159,9)\right.$ мкВ $\left.{ }^{2}\right)$, ніж в УГ $(74,9(46,8$; $129,0)$ мкB $\left.^{2}\right)$, так як і рівні АСПР тета-діапазону $\left(32,7(20,1 ; 68,4)\right.$ мкВ ${ }^{2}$ проти $20,0(10,0 ; 40,1)$ мкВ²).

Пацієнти, які вижили, в дебюті захворювання характеризувалися суттєво меншим переважанням повільнохвильової активності (значення інтегрального коефіцієнта DTABR в УГ та ІГ склали відповідно $1,46(0,61 ; 4,24)$ та $1,28(0,69 ; 3,74))$ без зсуву відносної спектральної потужності у 
Огляди літератури, оригінальні дослідження, погляд на проблему, випадок з практики, короткі повідомлення бік дельта-діапазону (значення інтегрального коефіцієнта DTR склали $0,95(0,46 ; 1,72)$ в УГ та $0,94(0,46 ; 1,43)$ в IГ). Аналіз значень інтегрального коефіцієнта ABR показав, що ритми альфадіапазону домінували над ритмами бета-діапазону як в УГ, так і в ІГ у пацієнтів обох груп, однак у когорті пацієнтів, які вижили, вказане переважання було статистично достовірно більш вагомим.

Результати уніваріантного логістичного регресійного аналізу показали, що досліджувані клініконеврологічні, нейровізуалізаційні та електроенцефалографічні показники асоційовані з ризиком летального виходу гострого періоду ССВМК (табл. 2).

Таблиця 2. Результати оцінки інформативності клініко-неврологічних, нейровізуалізаційних та електроенцефалографічних показників у визначенні індивідуального ризику летального виходу гострого періоду спонтанного супратенторіального внутрішньомозкового крововиливу за даними логістичного регресійного аналізу

\begin{tabular}{|c|c|c|c|c|}
\hline \multirow{3}{*}{ Показники } & \multicolumn{4}{|c|}{ Логістична регресійна модель } \\
\hline & \multicolumn{2}{|c|}{ уніваріантна } & \multicolumn{2}{|c|}{ мультиваріантна } \\
\hline & OR $(95 \% \mathrm{Cl})$ & $\mathrm{p}$ & OR $(95 \% \mathrm{Cl})$ & $\mathrm{p}$ \\
\hline Вік & $0,99(0,97-1,01)$ & 0,3393 & & \\
\hline FOUR score & $0,53(0,45-0,62)$ & $<0,0001$ & $0,30(0,13-0,69)$ & 0,0050 \\
\hline NIHSS score & $1,34(1,26-1,43)$ & $<0,0001$ & & \\
\hline OBMK & $1,06(1,04-1,07)$ & $<0,0001$ & $1,05(1,01-1,10)$ & 0,0270 \\
\hline Зсув прозорої перетинки & $1,52(1,38-1,67)$ & $<0,0001$ & & \\
\hline Зсув епіфізу & $1,61(1,43-1,80)$ & $<0,0001$ & & \\
\hline Наявність ВВШГ & $12,71(15,65-28,63)$ & $<0,0001$ & & \\
\hline АСПР дельта УГ & $1,02(1,01-1,03)$ & $<0,0001$ & & \\
\hline АСПР тета УГ & $1,01(1,01-1,03)$ & 0,0072 & & \\
\hline АСПР альфа УГ & $0,78(0,70-0,86)$ & $<, 0001$ & & \\
\hline АСПР бета УГ & $0,63(0,53-0,76)$ & $<0,0001$ & & \\
\hline АСПР загальна УГ & $1,01(1,00-1,01)^{*}$ & 0,0003 & & \\
\hline АСПР дельта ІГ & $1,02(1,01-1,03) *$ & $<0,0001$ & & \\
\hline АСПР тета ІГ & $1,01(1,00-1,02)^{*}$ & 0,0125 & & \\
\hline АСПР альфа ІГ & $0,84(0,78-0,91)$ & $<0,0001$ & & \\
\hline АСПР бета ІГ & $0,71(0,62-0,83)$ & $<0,0001$ & & \\
\hline АСПР загальна ІГ & $1,01(1,00-1,01)^{*}$ & 0,0002 & & \\
\hline DTABR УГ & $1,56(1,33-1,82)$ & $<0,0001$ & $1,70(1,14-2,53)$ & 0,0092 \\
\hline DTR УГ & $2,54(1,78-3,61)$ & $<0,0001$ & & \\
\hline DAR УГ & $1,53(1,33-1,77)$ & $<0,0001$ & & \\
\hline TAR УГ & $1,52(1,28-1,82) *$ & $<0,0001$ & & \\
\hline ABR УГ & $0,76(0,57-1,01)$ & 0,0594 & & \\
\hline DTABR IГ & $1,37(1,23-1,54)$ & $<0,0001$ & & \\
\hline DTR II & $2,04(1,54-2,70)$ & $<0,0001$ & $1,60(1,02-2,53)$ & 0,0412 \\
\hline DAR II & $1,34(1,21-1,47)$ & $<0,0001$ & & \\
\hline TAR II & $1,38(1,21-1,58)$ & $<0,0001$ & & \\
\hline ABR II & $0,61(0,48-0,84)$ & 0,0016 & & \\
\hline
\end{tabular}

Примітки: * - рівень значущості теста Хосмера-Лемешова $p<0,05$.

Застосування мультиваріантного логістичного регресійного аналізу дозволило ідентифікувати наступні незалежні предиктори летального виходу CCBMK: сумарний бал за шкалою коми FOUR (ВШ $(95 \%$ ДІ) $=0,30(0,13-0,69), p=0,0050)$, обсяг осередку ураження (ВШ (95\% ДІ) = 1,05 (1,01$1,10), p=0,0270)$, значення коефіцієнта DTABR в ураженій гемісфері (ВШ (95 \% ДІ) = 1,70 (1,14$1,53), p=0,0092)$, значення коефіцієнта DTR в інтактній півкулі (ВШ $(95 \%$ ДІ) = 1,60 (1,02-2,53), $\mathrm{p}=0,0412$ ).
Розроблена математична модель для визначення індивідуального ризику летального виходу гострого періоду ССВМК на тлі консервативної терапії, яка ґрунтується на результатах комплексного клініко-нейровізуалізаційно-електроенцефалографічного дослідження в дебюті захворювання і представлена рівнянням бінарної логістичної регресії наступного вигляду:

$$
\beta=9,26-1,21 \times P 1+0,05 \times P 2+0,53 \times P 3+0,47 \times P 4,
$$
де

9,26 - вільний член рівняння $\beta_{0}$ (intercept); 
Огляди літератури, оригінальні дослідження, погляд на проблему, випадок з практики, короткі повідомлення

P1 - сумарний бал за шкалою коми FOUR в першу добу ССВМК;

P2 - обсяг осередку ураження (мл) в першу добу ССВМК;

P3 - значення коефіцієнта DTABR ураженої гемісфери в перші 2 доби ССВМК;
P4 - значення коефіцієнта DTR інтактної гемісфери в перші 2 доби ССВМК.

На підставі ROC-аналізу встановлено, що значення $\beta>0,03 \epsilon$ інтегральним предиктором летального виходу гострого періоду ССВМК (чутливість - 90,5\%; специфічність - 100,0\%; AUC=0,99, p<0,0001) (рис. 1).



Рис. 1. ROC-крива розробленої математичної моделі для прогнозування летального виходу гострого періоду CСВМК на тлі консервативної терапії.

Питома вага вірно класифікованих спостережень з використанням зазначеної моделі склала 97,4 \% (рівень статистичної значущості тесту Хосмера-Лемешова $p=0,9992)$.

У результаті проведеного мультиваріантного логістичного регресійного аналізу в спектрі досліджуваних груп клініко-неврологічних, нейровізуалізаційних та електроенцефалографічних показників було ідентифіковано ті, що незалежно асоційовані з ризиком летального виходу гострого періоду ССВМК. Зокрема встановлено, що найінформативнішим клініко-неврологічним предиктором летального виходу $\epsilon$ значення сумарного бала за шкалою FOUR, яке кількісно відображає ступінь дисфункції субтенторіальних структур, обумовленої «масс-ефектом» півкульового внутрішньомозкового крововиливу. Отримані результати узгоджуються з даними інших досліджень, в яких було продемонстровано прогностичну цінність ініціального рівня неврологічного дефіциту в пацієнтів зі спонтанним внутрішньомозковим крововиливом $[8,9,11]$. У нашому попередньому дослідженні була доведена висока діагностична інформативність шкали коми FOUR у детекції клі- нічних проявів зсуву серединних структур мозку в гострому періоді ССВМК [20].

Серед нейровізуалізаційних показників до мультиваріантної логістичної регресійної моделі увійшов обсяг осередку ураження, який в інтеграції з перифокальним набряком ініціює дислокацію стовбурових структур і реалізує прогредієнтний перебіг захворювання, що узгоджується 3 результатами інших досліджень [21, 22].

Найбільш інформативними електроенцефалографічними показниками для прогнозування летального виходу гострого періоду ССВМК виявилися значення інтегрального коефіцієнта DTABR ураженої гемісфери та інтегрального коефіцієнта DTR інтактної гемісфери. Перший показник відображає питому вагу повільнохвильової активності в структурі ЕЕГ-патерна, другий - деталізує структуру повільнохвильової активності в інтактній гемісфері. У результаті порівняльного аналізу встановлено, що пацієнти, в яких гострий період ССВМК мав ЛВ, у перші 2 доби від дебюту захворювання відрізнялися білатеральним домінуванням повільнохвильової активності переважно дельта-діапазону внаслідок депресії рит- 
Огляди літератури, оригінальні дослідження, погляд на проблему, випадок з практики, короткі повідомлення мів альфа- та бета-діапазонів, на користь чого свідчили рівні абсолютної спектральної потужності відповідних ритмів та значення інтегральних коефіцієнтів DTABR, DAR. Зазначені зміни ЕEГ-патерну відображали глибоку депресію висхідної активуючої ретикулярної системи у зазначеної когорти пацієнтів унаслідок суттєво більш вираженої дислокації стовбурових структур. Наявність інтегрального коефіцієнта DTABR ураженої гемісфери в структурі розробленої мультиваріантної логістичної регресійної моделі узгоджується з даними інших досліджень, в яких було продемонстровано прогностичну цінність питомої ваги повільнохвильової активності у пацієнтів з гострими ураженнями головного мозку ішемічного та травматичного генезу $[17,18,23]$. Рівень коефіці$\epsilon$ нта DTABR ураженої гемісфери $\epsilon$ також електроенцефалографічним маркером тяжкості ураження специфічних систем мозку супратенторіальної локалізації.

На користь провідної ролі ступеня дисфункції субтенторіальних структур унаслідок «масс-ефекту» в реалізації прогредієнтного перебігу гострого періоду ССВМК також свідчить наявність у структурі розробленої мультиваріантної логістичної регресійної моделі інтегрального коефіцієнта DTR інтактної гемісфери. Виявлено, що пацієнти, в яких гострий період ССВМК мав ЛВ, в перші 2 доби від дебюту захворювання відрізнялися більш високими рівнями АСПР дельта-діапазону інтактної гемісфери, порівняно з ураженою. Отримані результати узгоджуються з даними інших досліджень, в яких було показано, що формування міжпівкульової асиметрії за рахунок більш високої потужності ритмів дельта-діапазону в інтактній гемісфері відображає тяжке ураження церебральних структур, інтегроване з явищами інтергемісферного діашизу в найгострішому періоді мозкового інсульту $[24,25]$. У нашому попередньому дослідженні також було продемонстровано, що білатеральна елевація повільнохвильової активності у хворих на ССВМК асоційована з більш вираженим латеральним зсувом стовбурових структур [26].

Розробка математичної моделі дозволила інтегрувати найбільш інформативні клініко-неврологічні, нейровізуалізаційні, електроенцефалографічні показники і отримати комплексний прогностичний критерій. За даними ROC-аналізу було визначено порогове значення цього показника, яке дозволяє визначати короткостроковий прогноз з оптимальним співвідношенням чутливості та специфічності. Узгодження математичної моделі з реальними даними було верифіковане за такими показниками: 1) питома вага вірно класифікованих спостережень (97,4 \%); 2) тест Хосме-

ра-Лемешова $(p>0,05) ; 3)$ площа під характеристичною операційною кривою $(A \cup C=0,99)$, яка відображає співвідношення істинно позитивних та хибно позитивних результатів класифікації спостережень, з наступною оцінкою за міжнародною шкалою визначення якості бінарних класифікаторів М. H. Zweig, G. Campbell (1993) [27].

Усе викладене обґрунтовує доцільність використання розробленої математичної моделі в рутинній клінічній практиці в якості інформативного інструменту стратифікації індивідуального ризику летального виходу гострого періоду ССВМК на тлі консервативної терапії в якості підґрунтя для прийняття оптимальних лікувально-тактичних рішень.

Висновки. 1. 3 ризиком летального виходу гострого періоду спонтанного супратенторіального внутрішньомозкового крововиливу на тлі консервативної терапії незалежно асоційовані такі критерії оцінки тяжкості ураження церебральних структур у дебюті захворювання: вираженість загальномозкового синдрому, обсяг осередку ураження, питома вага повільнохвильової активності в ураженій гемісфері та зсув спектральної потужності повільнохвильової активності у бік дельтадіапазону в інтактній гемісфері.

2. Розроблена математична модель для прогнозування летального виходу гострого періоду спонтанного супратенторіального внутрішньомозкового крововиливу на тлі консервативної терапії (AUC=0,99, $p<0,0001)$, яка ґрунтується на результатах комплексного клініко-нейровізуалізаційно-електроенцефалографічного дослідження в дебюті захворювання і враховує наступні показники: сумарний бал за шкалою коми FOUR (ВШ (95\% ДI) $=0,29(0,13-0,69), p=0,0050)$, обсяг осередку ураження (ВШ $(95 \%$ ДI) $=1,05(1,01-1,10), p=0,0270)$, значення коефіцієнта DTABR в ураженій гемісфері (ВШ $(95 \%$ ДI)=1,70 (1,14-1,53), $p=0,0092)$ та коефіцієнта DTR в інтактній півкулі (ВШ (95\% ДІ)=1,60 $(1,02-2,53), p=0,0412)$.

3. Визначений високочутливий та високоспецифічний комплексний критерій, який інтегрує діагностичну інформативність результатів клініко-неврологічного, нейровізуалізаційного та електроенцефалографічного досліджень у дебюті спонтанного супратенторіального внутрішньомозкового крововиливу і дозволяє прогнозувати летальний вихід гострого періоду захворювання на тлі консервативної терапії з точністю до 97,4 \%.

Перспективою подальших досліджень $\epsilon$ розробка диференційованого підходу до визначення оптимальної лікувальної тактики у пацієнтів зі ССВМК у гострому періоді захворювання з урахуванням короткострокового вітального прогнозу. 


\section{ЛІТЕРАТУРА}

1. Katan M. Global burden of stroke / M. Katan, A. Luft // Semin. Neurol. -2018. - Vol. 38 (2). - P. 208-211.

2. Demographic and epidemiologic drivers of global cardiovascular mortality. New England Journal of Medicine / G. A. Roth, M. H. Forouzanfar, A. E. Moran [et al.] // New England Journal of Medicine. - 2015. - Vol. 372. P. 1333-1341.

3. Deopujari C. Spontaneous intracerebral hemorrhage / C. Deopujari, S. Shaikh // Neurol India. - 2018. Vol. 66(6). - P.1704-1705.

4. Адаптована клінічна настанова «Геморагічний інсульт. Спонтанний внутрішньомозковий крововилив» - Режим доступу : http://mtd.dec.gov.ua/images/ dodatki/2014_275_Gl/2014_275_AKN_vnytrkrov_Gl.pdf

5. Thabet A. M. Management of intracerebral hemorrhage / A. M. Thabet, M. Kottapally, J. C. 3rd Hemphill // Handb. Clin. Neurol. - 2017. - Vol. 140. - P. 177-194.

6. Intracerebral hemorrhage outcome: A comprehensive update / J. Pinho, A. S. Costa, J. M. Araújo [et al.] // J. Neurol. Sci. - 2019. - Vol. 398. - P. 54-66.

7. Intracerebral hemorrhage in intensive care unit: early prognostication fallacies. A single center retrospective study / S. Spina, C. Marzorati, A. Vargiolu [et al.] // Minerva Anestesiol. - 2018. - Vol. 84 (5). - P. 572-581.

8. Kuznietsov A. A. Integral clinical and neuroimaging criteria for the prognosis of spontaneous supratentorial intracerebral hemorrhage acute period outcome / A. A. Kuznietsov // Zaporozhye Medical Journal. - 2018. Vol. 20 (2). - P. 152-156.

9. Predictors of 30-day mortality in patients with spontaneous primary intracerebral hemorrhage / D. A. Safatli, A. Günther, P. Schlattmann [et al.] // Surg. Neurol. Int. - 2016. - Vol. 7 (Suppl. 18). - P. 510-517.

10. Intracerebral hemorrhage location and functional outcomes of patients: A systematic literature review and meta-analysis / A. Sreekrishnan, J. L. Dearborn, D. M. Greer [et al.] // Neurocrit. Care. - 2016. - Vol. 25 (3). - P. 384-391.

11. Prognostic factors of clinical outcomes in patients with spontaneous thalamic hemorrhage / S. H. Lee, K. J. Park, S. H. Kang [et al.] // Med. Sci. Monit. - 2015. - Vol. 5 (21). P. 2638-2646.

12. Kuznietsov A. Possibilities of clinical neuroimaging assessment scales using for patient severity in the onset of cerebral hemorrhagic supratentorial stroke to predict the outcome of the disease acute period / A. Kuznietsov // Zaporozhye Medical Journal. - 2018. - Vol. 20 (1). - P. 47-50.

13. Prognostic models for intracerebral hemorrhage: systematic review and meta-analysis / T. Gregório, S. Pipa, P. Cavaleiro [et al.] // BMC Med. Res. Methodol. - 2018. Vol. 18. - P.145.

14. The role of quantitative EEG in the diagnosis of neuropsychiatric disorders / L. Livint Popa, H. Dragos, C. Pantelemon // J. Med. Life. - 2020. - Vol. 13 (1). - P. 8-15.

15. Utility of EEG measures of brain function in patients with acute stroke / J. Wu, R. Srinivasan, E. Burke Quinlan [et al.] // J. Neurophysiol. - 2016. - Vol. 115 (5). P. 2399-2405.
16. Predicting the non-survival outcome of large hemispheric infarction patients via quantitative electroencephalography: Superiority to visual electroencephalography and the Glasgow Coma Scale / M. Jiang, Y. Su, G. Liu [et al.] // Neurosci. Lett. - 2019. - Vol. 706. - P. 88-92.

17. Prediction of the functional outcome of cerebral ischemic supratentorial stroke acute period on the basis of spectral analysis of the brain bioelectrical activity / A. A. Kuznietsov // Zaporozhye Medical Journal. - 2018. Vol. 20 (3). - P. 324-329.

18. Quantitative EEG Parameters for Prediction of Outcome in Severe Traumatic Brain Injury: Development Study / A. Tolonen, M. O. K. Särkelä, R. S. K Takala [et al.] // Clin EEG Neurosci. - 2018. - Vol. 49 (4). - P. 248-257.

19. Уніфікований клінічний протокол екстреної, первинної, вторинної (спеціалізованої), третинної (високоспеціалізованої) медичної допомоги та медичної реабілітації «Геморагічний інсульт (внутрішньомозкова гематома, аневризмальний субарахноїдальний крововилив). - Режим доступу : http://moz.gov.ua/docfiles/ dod275_ukp_2014.pdf

20. Kuznietsov A. A. Analysis of diagnostic informative value of the Full Outline of UnResponsiveness Scale in patients with spontaneous supratentorial intracerebral hemorrhage / A. A. Kuznietsov // Zaporozhye Medical Journal. - 2019. - Vol. 21 (1). - P. 33-38.

21. Hematoma volume as the major determinant of outcomes after intracerebral hemorrhage / M. A. LoPresti, S. S. Bruce, E. Camacho [et al.] // J. Neurol. Sci. - 2014. Vol. 345 (1-2). - P. 3-7.

22. Panchal H. N. Intracerebral hemorrhage score and volume as an independent predictor of mortality in primary intracerebral hemorrhage patients / N. H. Panchal, M. S. Shah, D. S. Shah // Indian J. Surg. - 2015. - Vol. 77 (Suppl. 2). - P. 302-304.

23. Finnigan S. Defining abnormal slow EEG activity in acute ischaemic stroke: Delta/alpha ratio as an optimal QEEG index / S. Finnigan, A. Wong, S. Read // Clin Neurophysiol. - 2016. - Vol. 127 (2). - P.1452-1459.

24. Finnigan S.P. Contralateral hemisphere delta EEG in acute stroke precedes worsening of symptoms and death / S. P. Finnigan, S. E. Rose, J. B. Chalk // Clin. Neurophysiol. - 2008. - Vol. 119 (7). - P. 1690-1694.

25. A contralesional EEG power increase mediated by interhemispheric disconnection provides negative prognosis in acute stroke / G. Assenza, F. Zappasodi, P. Pasqualetti [et al.] // Restor Neurol Neurosci. - 2013. - Vol. 31(2). P. $177-188$

26. Kuznietsov A. A. Diagnostic value of the integral assessment of electroencephalographic pattern in patients in the acute period of spontaneous supratentorial intracerebral hemorrhage / A. A. Kuznietsov // Patologia. - 2018. Vol. 15 (3). - P. 378-385.

27. Zweig M. H. Receiver-operating characteristic (ROC) plots: a fundamental evaluation tool in clinical medicine / M. H. Zweig, G. Campbell // Clin. Chem. - 1993. Vol. 39 (4). - P. 561-577. 

REFERENCES

1. Katan, M., \& Luft, A. (2018). Global burden of stroke. Semin. Neurol., 38 (2), 208-211. DOI: 10.1055/s-00381649503.

2. Roth, G.A., Forouzanfar, M.H., Moran, A.E., Barber, R., Nguyen, G., Feigin, V.L., Naghavi, M., etal. (2015). Demographic and epidemiologic drivers of global cardiovascular mortality. New England Journal of Medicine, 372, 1333-1341. DOI: 10.1056/NEJMoa1406656.

3. Deopujari, C., \& Shaikh, S. (2018). Spontaneous intracerebral hemorrhage. Neurol. India, 66 (6), 1704-1705. DOI: 10.4103/0028-3886.246300.

4. (2014). Adaptovana klinichna nastanova "Hemorahichnyi insult. Spontannyi vnutrishnomozkovyi krovovylyv" Ministerstvo okhorony zdorovia Ukrainy [Adapted clinical guidance "Hemorrhagic stroke. Subarachnoid hemorrhage" Ministry of Health of Ukraine]. Retrieved from: http://mtd.dec.gov.ua/images/dodatki/2014_275_ Gl/2014_275_AKN_vnytrkrov_Gl.pdf [in Ukrainian].

5. Thabet, A.M., Kottapally, M., \& Hemphill, J.C. 3rd. (2017). Management of intracerebral hemorrhage. Handb. Clin. Neurol., 140, 177-194. DOI: 10.1016/B978-0-44463600-3.00011-8.

6. Pinho, J., Costa, A.S., Araújo, J.M., Amorim, J.M., \& Ferreira, C. (2019) Intracerebral hemorrhage outcome: A comprehensive update. J. Neurol. Sci., 398, 54-66. DOI: 10.1016/j.jns.2019.01.013.

7. Spina, S., Marzorati, C., Vargiolu, A., Magni, F., Riva, M., Rota, M., Giussani, C., Sganzerla, E.P., \& Citerio, G. (2018). Intracerebral hemorrhage in intensive care unit: early prognostication fallacies. A single center retrospective study. Minerva Anestesiol., 84 (5), 572-581. DOI: 10.23736/ S0375-9393.17.12225-X.

8. Kuznietsov, A.A. (2018). Integral clinical and neuroimaging criteria for the prognosis of spontaneous supratentorial intracerebral hemorrhage acute period outcome. Zaporozhye Medical Journal, 2018, 20 (2), 152-156. DOI: $10.14739 / 2310-1210.2018 .02 .124820$.

9. Safatli, D.A., Günther, A., Schlattmann, P., Schwarz, F., Kalff, R., \& Ewald, C. (2016). Predictors of 30-day mortality in patients with spontaneous primary intracerebral hemorrhage. Surg. Neurol. Int., 7 (Suppl. 18), 510-517. DOI: $10.4103 / 2152-7806.187493$.

10. Sreekrishnan, A., Dearborn, J.L., Greer, D.M., Shi, F.D., Hwang, D.Y., Leasure, A.C., Zhou, S.E., et al. (2016). Intracerebral hemorrhage location and functional outcomes of patients: A systematic literature review and metaanalysis. Neurocrit. Care, 25 (3), 384-391.

11. Lee, S.H., Park, K.J., Kang, S.H., Jung, Y.G., Park, J.Y., \& Park, D.H. (2015). Prognostic factors of clinical outcomes in patients with spontaneous thalamic hemorrhage. Med. Sci. Monit., 5 (21), 2638-2646. DOI: 10.12659/MSM.894132.

12. Kuznietsov, A. (2018). Possibilities of clinical neuroimaging assessment scales using for patient severity in the onset of cerebral hemorrhagic supratentorial stroke to predict the outcome of the disease acute period. Zaporozhye Medical Journal, 20 (1), 47-50. DOI: 10.14739/23101210.2018.1.121990.

13. Gregório, T., Pipa, S., Cavaleiro, P., Atanásio, G., Albuquerque, I., Chaves, P.C., \& Azevedo, L. (2018). Prognostic models for intracerebral hemorrhage: systematic re- view and meta-analysis. BMC Med. Res. Methodol., 18, 145. DOI: 10.1186/s12874-018-0613-8.

14. Livint Popa, L., Dragos, H., Pantelemon, C., Verisezan Rosu, O., \& Strilciuc, S. (2020). The role of quantitative EEG in the diagnosis of neuropsychiatric disorders. J. Med. Life, 13 (1), 8-15. DOI: 10.25122/jml-2019-0085.

15. Wu, J. Srinivasan, R. Burke Quinlan, E. Solodkin A., Small, S.L., \& Cramer, S.C. (2016). Utility of EEG measures of brain function in patients with acute stroke. J. Neurophysiol., 115 (5), 2399-2405. DOI: 10.1152/jn.00978.2015.

16. Jiang, M., Su, Y., Liu, G., Chen, W., \& Gao, D. (2019). Predicting the non-survival outcome of large hemispheric infarction patients via quantitative electroencephalography: Superiority to visual electroencephalography and the Glasgow Coma Scale. Neurosci. Lett., 706, 88-92. DOI: 10.1016/j.neulet.2019.05.007.

17. Kuznietsov, A.A. (2018). Prediction of the functional outcome of cerebral ischemic supratentorial stroke acute period on the basis of spectral analysis of the brain bioelectrical activity. Zaporozhye Medical Journal, 20 (3), 324-329. DOI: 10.14739/2310-1210.2018.3.132127.

18. Tolonen, A., Särkelä, M.O.K., Takala, R.S.K., Katila, A., Frantzén, J., Posti, J.P., Müller, M., van Gils M., \& Tenovuo, O. (2018). Quantitative EEG parameters for prediction of outcome in severe traumatic brain injury: Development study. Clin EEG Neurosci., 49 (4), 248-257. DOI: 10.1177/1550059417742232.

19. (2014). Unifikovanyi klinichnyi protokol ekstrenoi, pervynnoi, vtorynnoi (spetsializovanoi), tretynnoi (vysokospetsializovanoi) medychnoi dopomohy ta medychnoi reabilitatsii "Hemorahichnyi insult (vnutrishnomozkova hematoma, anevryzmalnyi subarakhnoyidalnyi krovovylyv)". Ministry of Health of Ukraine. Retrieved from: http://moz. gov.ua/docfiles/dod275_ukp_2014.pdf.

20. Kuznietsov, A.A. (2019). Analysis of diagnostic informative value of the Full Outline of UnResponsiveness Scale in patients with spontaneous supratentorial intracerebral hemorrhage. Zaporozhye Medical Journal, 21 (1), 33-38. DOI: 10.14739/2310-1210.2019.1.155799.

21. LoPresti, M.A., Bruce, S.S., Camacho, E., Kunchala, S., Dubois, B.G., Bruce, E., Appelboom, G., \& Connolly, E.S.Jr. (2014). Hematoma volume as the major determinant of outcomes after intracerebral hemorrhage. J. Neurol. Sci., 345 (1-2), 3-7. DOI: 10.1016/j.jns.2014.06.057.

22. Panchal, H.N., Shah, M.S., \& Shah, D.S. (2015). Intracerebral hemorrhage score and volume as an independent predictor of mortality in primary intracerebral hemorrhage patients. Indian J. Surg., 77 (Suppl. 2), 302-304. DOI: $10.1007 / \mathrm{s} 12262-012-0803-2$.

23. Finnigan, S., Wong, A., \& Read, S. (2016) Defining abnormal slow EEG activity in acute ischaemic stroke: Delta/alpha ratio as an optimal QEEG index. Clin. Neurophysiol., 127 (2), 1452-1459. DOI: 10.1016/j.clinph. 2015.07.014.

24. Finnigan, S.P., Rose, S.E., \& Chalk, J.B. (2008). Contralateral hemisphere delta EEG in acute stroke precedes worsening of symptoms and death. Clin. Neurophysiol., 119 (7), 1690-1694. DOI: 10.1016/j.clinph.2008.03.006.

25. Assenza, G., Zappasodi, F., Pasqualetti, P., Vernieri, F., \& Tecchio, F. (2013). A contralesional EEG power increase mediated by interhemispheric disconnection pro- 
Огляди літератури, оригінальні дослідження, погляд на проблему, випадок з практики, короткі повідомлення vides negative prognosis in acute stroke. Restor. Neurol. Neurosci., 31 (2), 177-188. DOI: 10.3233/RNN-120244.

26. Kuznietsov, A.A. (2018). Diagnostic value of the integral assessment of electroencephalographic pattern in patients in the acute period of spontaneous supratentorial

intracerebral hemorrhage. Patologia, 15 (3), 378-385. DOI: 10.14739/2310-1237.2018.3.151869.

27. Zweig, M.H., \& Campbell, G. (1993). Receiver-operating characteristic (ROC) plots: a fundamental evaluation tool in clinical medicine. Clin. Chem., 39 (4), 561-577.

\title{
ВОЗМОЖНОСТИ ВЕРИФИКАЦИИ КРАТКОСРОЧНОГО ВИТАЛЬНОГО ПРОГНОЗА У ПАЦИЕНТОВ СО СПОНТАННЫМ СУПРАТЕНТОРИАЛЬНЫМ ВНУТРИМОЗГОВЫМ КРОВОИЗЛИЯНИЕМ НА ФОНЕ КОНСЕРВАТИВНОЙ ТЕРАПИИ НА ОСНОВАНИИ КОМПЛЕКСНОГО КЛИНИКО-НЕЙРОВИЗУАЛИЗАЦИОННО- ЭЛЕКТРОЭНЦЕФАЛОГРАФИЧЕСКОГО ИССЛЕДОВАНИЯ
}

\author{
๑А. А. Козелкин, А. А. Кузнецов \\ Запорожский государственный медицинский университет МОЗ Украины
}

РЕЗЮМЕ. Цель - разработать интегральные критерии прогнозирования летального исхода острого периода спонтанного супратенториального внутримозгового кровоизлияния на фоне консервативной терапии, основанные на результатах комплексного клинико-нейровизуализационно-электроэнцефалографического исследования.

Материал и методы. Проведено проспективное когортное сравнительное исследование 156 пациентов в остром периоде спонтанного супратенториального внутримозгового кровоизлияния на фоне консервативной терапии, которые были госпитализированы в течение 24 часов от дебюта заболевания. Клинико-неврологическое исследование включало оценку по шкале комы Full Outline of UnResponsiveness и National Institute of Health Stroke Scale. Визуализацию церебральных структур осуществляли методом компьютерной томографии. Электроэнцефалографическое исследование проводилось в первые 48 часов, при этом отдельно для пораженной и интактной гемисфер определялись уровни абсолютной спектральной мощности ритмов дельта-, тета-, альфа-, бетадиапазонов с последующим расчетом интегральных коэффициентов, отражающих различные соотношения указанных выше ритмов. Для разработки критериев прогнозирования применяли логистический регрессионный анализ и ROCанализ.

Результаты. Летальный исход в течение острого периода заболевания был зафиксирован в 42 (26,9 \%) случаях. На основании мультивариантного логистического регрессионного анализа было установлено, что с риском летального исхода острого периода спонтанного супратенториального внутримозгового кровоизлияния на фоне консервативной терапии независимо ассоциированы следующие клинико-нейровизуализационно-электроэнцефалографические критерии оценки тяжести поражения церебральных структур в дебюте заболевания: суммарный балл по шкале комы Full Outline of UnResponsiveness (ОШ (95 \% ДИ) = 0,29 (0,13-0,69), p=0,0050), объем очага поражения (ОШ (95\% ДИ) = 1,05 (1,01-1,10), p=0,0270), значение коэффициента DTABR в пораженной гемисфере (ОШ $95 \%$ ДИ) = 1,70 (1,14-1,53), p=0,0092) и коэффициента DTR в интактной гемисфере (ОШ $(95 \%$ ДИ) = 1,60 (1,022,53), $p=0,0412$ ).

Выводы. Разработана математическая модель для прогнозирования летального исхода острого периода спонтанного супратенториального внутримозгового кровоизлияния на фоне консервативной терапии, основанная на результатах комплексного клинико-нейровизуализационно-электроэнцефалографического исследования в дебюте заболевания (AUC = 0,99, p<0,0001, точность прогнозирования 97,4 \%).

КЛючЕВЫЕ СЛОВА: внутримозговое кровоизлияние; компьютерная томография; электроэнцефалография; витальный прогноз.

\section{POSSIBILITIES OF SHORT-TERM SPONTANEOUS SUPRATENTORIAL INTRACEREBRAL HAEMORRHAGE VITAL PROGNOSIS VERIFICATION DURING CONSERVATIVE THERAPY ON THE GROUND OF COMPLEX CLINICAL, NEUROVISUALIZATION INVESTIGATION AND ELECTROENCEPHALOGRAPHY DATA}

\author{
○O. A. Kozyolkin, A. A. Kuznietsov \\ Zaporizhzhia State Medical University
}

SUMMARY. The aim - to elaborate the integrated prognostic criteria for spontaneous supratentorial intracerebral hemorrhage (SSICH) lethal outcome that are based on the data of complex clinical, neurovisualization and electroencephalographic investigations on the ground of conservative therapy. 
Огляди літератури, оригінальні дослідження, погляд на проблему, випадок з практики, короткі повідомлення

Material and Methods. Prospective, cohort and comparative study was conducted in 156 patients in SSICH acute period on the ground of conservative therapy, who were admitted during 24 hours from the disease onset. Clinical and neurological investigation included evaluation according to Full Outline of UnResponsiveness and National Institute of Health Stroke Scale. Cerebral structures detection was made by using computed tomography. Electroencephalography was performed in the first 48 hours. Thus, values of absolute spectral rhythm power of delta, theta, alpha, beta bands were evaluated separately for affected and intact hemispheres. Than integrated coefficients that reflect different balance of mentioned indexes were calculated. Logistic regression and ROC-analysis were used for elaboration of prognostic criteria.

Results. Lethal outcome during acute period of SSICH was detected in $42(26.9 \%)$ cases. It was revealed that summary score according to coma Full Outline of UnResponsiveness scale (OR $(95 \% \mathrm{Cl})=0.29(0.13-0.69), \mathrm{p}=0.0050)$, intracerebral hemorrhage volume $(\mathrm{OR}(95 \% \mathrm{Cl})=1.05(1.01-1.10), \mathrm{p}=0.0270)$, value of DTABR in affected hemisphere $(\mathrm{OR}(95 \% \mathrm{Cl})=1.70(1.14-1.53), \mathrm{p}=0.0092)$ and DTR coefficient in intact hemisphere $(\mathrm{OR}(95 \% \mathrm{Cl})=1.60(1.02-2.53)$, $\mathrm{p}=0.0412$ ) were independently associated with the risk of lethal SSICH outcome against the conservative therapy on the ground of multivariate logistic regression analysis.

Conclusions. The mathematic model for SSICH lethal outcome prediction against the conservative therapy was elaborated. It is based on results of complex clinical, neurovisualization and electroencephalographic investigations in the onset of the disease ( $A \cup C=0.99, \mathrm{p}<0.0001$; predictive accuracy $97.4 \%$ ).

KEY WORDS: intracerebral hemorrhage; computed tomography; electroencephalography; vital prognosis.

Отримано 22.08.2020 